What makes ISAF s/tick: An investigation of the politics of coalition burden-sharing ${ }^{1}$

\title{
Authors:
}

Péter Marton, Corvinus University of Budapest, Hungary

pmarton@gmail.com

$\&$

Nik Hynek, Institute of International Relations in Prague, the Czech Republic hynek@iir.cz

For correspondence related to this paper, contact Péter Marton at pmarton@gmail.com

Paper presented at the ISA 2012 Convention in San Diego, California, 1-4 April 2012 (Panel: "Coalitions and counterinsurgency in Afghanistan and Iraq").

\footnotetext{
${ }^{1}$ This paper is built on earlier work, and contains the previously unpublished synthesis of research, in Hynek, Nik and Marton, Péter, eds. (2011) 'Statebuilding in Afghanistan: Multinational contributions to reconstruction'. London: Routledge; it also takes that research forward in new directions.
} 


\section{What makes ISAF s/tick: An investigation of the politics of coalition burden-sharing}

\section{Introduction}

This paper is interested in conceptualising the often raised issue of over- and under-contributing in coalition operations; that of how and why members of complex coalitions ${ }^{2}$ may be punching above and below their weight, respectively. To this end, the first section presents a parsimonious baseline assumption regarding what variables may fundamentally inform coalition burden-sharing, to subsequently discuss how much each of these are found to play a role in the Afghanistan context. The second section elaborates on this by assessing the perception and the interpretation of threats by coalition member countries, related to Afghanistan, as this pertains to prioritising other variables within the scheme outlined in the previous section. The third and fourth sections then proceed to examine and further enrich the existing literature on coalition burden-sharing, and provide further insights regarding the operations of the International Security Assistance Force-Afghanistan, and regarding ISAF member-country decisionmaking; the objective here is to generate further refined assumptions, that can permit a preliminary assessment of the phenomenon of uneven burden-sharing in ISAF, complementing the initial baseline expectations.

Preliminary findings are presented in the fifth section where we offer raw evidence of the relevance of our baseline assumptions. In the sixth section, we present integrated models of the key variables that play a role in shaping coalition contributions, and here two key periods form the focus of this study. On the one

\footnotetext{
${ }^{2}$ The use of the adjective "complex" may be warranted given that the mission in Afghanistan is a joint, combined, interagency effort, or in other words a multinational "whole-of-government engagement" integrating $\mathrm{IGO} / \mathrm{NGO}$ efforts as well, and, at the same time, as Bensahel points out, a coalition within a coalition of coalitions (2006).
} 
hand, we focus on the period of ISAF's cross-country involvement in Afghanistan, following ISAF's expansion of its operations to the south of Afghanistan in mid2006, up to mid-2011, i.e. the official end point of the US-led "surge" effort, intended to provide "Max" or peak leverage against insurgents, in the hope of achieving certain limited objectives in Afghanistan. On the other hand, we similarly reflect on the larger time interval of ISAF's entire lifespan.

We can subsequently, in the seventh section, draw conclusions as to how the distribution of countries with different approaches or "commitment postures" may have affected Afghanistan strategy and developments on the ground in the context of the ongoing insurgencies. In the final section, we refine our initial baseline assumptions and the hypothesised country profiles which were based on the latter, with reference to a recently published collection of country case studies by a team of scholars (in Hynek and Marton 2011) which tested our baseline assumptions in the cases of some of the countries concerned.

\section{A baseline assessment of coalition contributions}

With US President Obama's December 2009 speech, the mission in Afghanistan seemed headed once again - after the initial period following the 2001 intervention - towards increasing "Americanisation" of its overall project. Whether the allies of the United States failed or not to pull their weight over the intervening period may seem to be a relevant question in light of this; one that is in fact likely to permeate NATO discussions and debates over the Alliance for the foreseeable future. Yet, regarding Afghanistan, there has been no systematic attempt in the academic literature to identify the key factors affecting (i) the qualitative and (both the relative and the absolute) quantitative character of coalition member country contributions; (ii) motives explaining their involvement in Afghanistan and in ISAF overall; (iii) the quality of adaptation demonstrated by them once on the ground there; and (iv) the role of local factors in individual countries' areas of operations in 
shaping outcomes with regards to factors $i$-iii. This is all the more puzzling given the extensive literature on coalition burden-sharing on the one hand, ${ }^{3}$ and the current, considerably high interest in Afghanistan on the other. The above listed factors all pertain to assessing if certain countries under-contributed to, or underperformed in, the mission in a relative sense, and why this may have been the case.

Figure 1.1: The alliance dependence/threat balancing matrix

\begin{tabular}{|c|c|c|c|}
\hline & \multicolumn{2}{|c|}{ Alliance dependence } \\
\hline & & Weak & Strong \\
\hline \multirow[t]{2}{*}{$\begin{array}{l}\text { Threat } \\
\text { balancing }\end{array}$} & Weak & "onlookers" & "servants" \\
\hline & $\begin{array}{l}\text { Stron } \\
g\end{array}$ & "mavericks" & "strivers" \\
\hline
\end{tabular}

A simple framework of assessment, based partly on Bennett, Lepgold \& Unger (1994) whose work will be discussed in more detail later on, reckons with alliance dependence and threat balancing as the key structural motives factoring in coalition members' Afghanistan policies. Put differently, this may suggest that countries either entered Afghanistan, and stayed there over the years, because they needed to do so themselves, or because they were compelled to do so by others who did. This allows for generating a simple set of hypotheses. These can be best

\footnotetext{
${ }^{3}$ See Bennett, Lepgold and Unger 1994; Khanna and Sandler 1996; Hartley and Sandler 1999; DiNardo and Hughes 2001; Shimizu and Sandler 2003; Auerswald 2004 and 2010; Wilkins 2006; Kreps 2007; Fang and Ramsay 2008; Ringsmose 2009; Kreps 2010.
} 
outlined if one portrays the variations of possible interplays between the factors of threat balancing and alliance dependence in a two-by-two matrix (Figure 1.1).

A common-sense hypothesis is that those countries will commit more, both in terms of quantity and quality, to the coalition's mission that see a need to "balance" threats in Afghanistan, and at the same time value the NATO alliance, or the alliance of one or more key NATO countries within the NATO bloc ("strivers"). Conversely, the weakest motivation is expected to be observed in cases where both threat perceptions and strong alliance dependence are absent ("onlookers"). The more interesting cases are those where either only threat balancing or alliance dependence appears as an influential factor: that is where theory may need to be further formulated and developed regarding the issues of coalition burden-sharing and coalition management. It is anticipated, nevertheless, that the majority of the coalition may be reminiscent of "servants". Some of the possible candidates for each of these categories, with rudimentary rationalization indicated, are placed in Figure 1.2.

Figure 1.2: Hypothesised country profiles

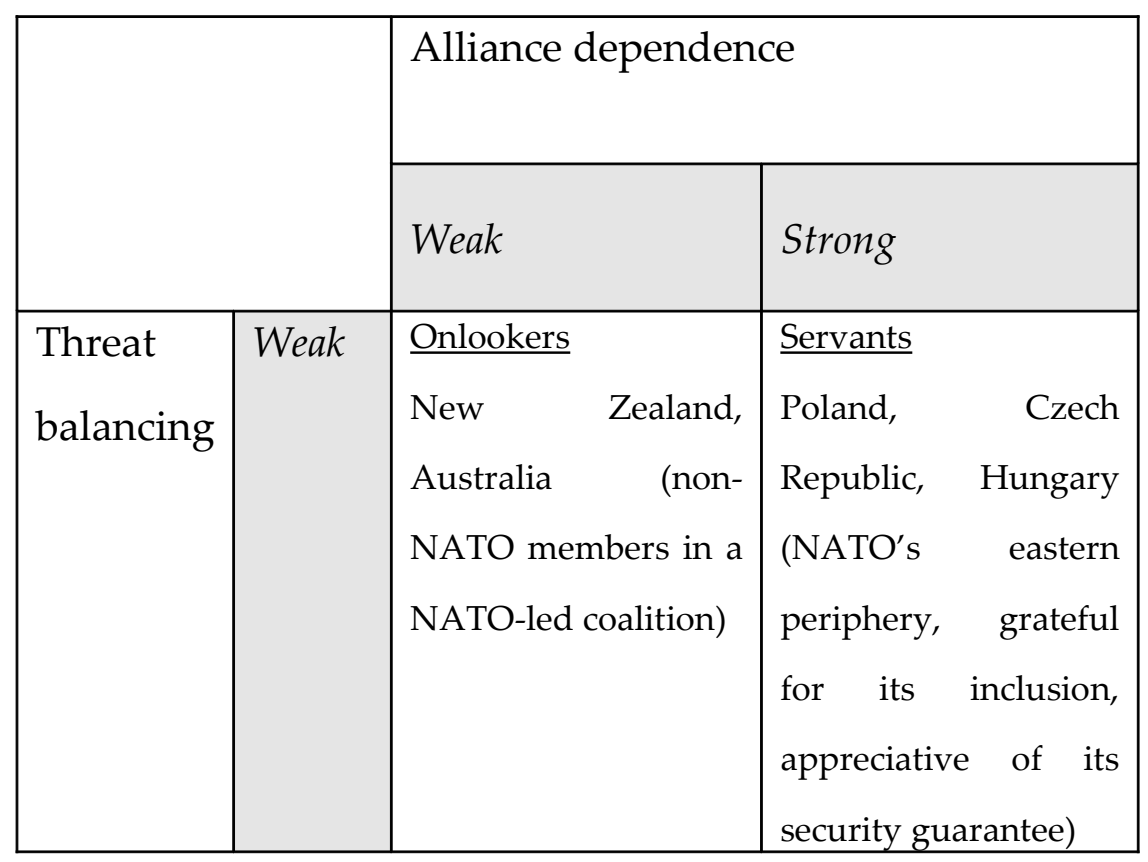




\begin{tabular}{|l|l|l|l|}
\hline & $\begin{array}{l}\text { Mavericks } \\
\text { Stron }\end{array}$ & $\begin{array}{l}\text { France (given its } \\
\text { tradition of a special } \\
\text { approach to NATO } \\
\text { cooperation) }\end{array}$ & $\begin{array}{l}\text { United Kingdom, } \\
\text { Spain (having been } \\
\text { attacked by al-Qaida) }\end{array}$ \\
\hline
\end{tabular}

The alliance dependence/threat balancing framework offers the advantage of parsimony, but it may be impractically constraining at the same time. It is expected that its dual categorisation of policy motives needs to be refined and complemented. One possible objection to the threat balancing/alliance dependence framework is that it is grounded in a neorealist/materialist understanding of politics whereby only material costs and benefits, and related pressures and interests, seem to matter to state decision-makers. In this ontology, there is seemingly no place for intangible values. ${ }^{4}$

A more dynamic approach may also be necessary. Adaptation to the local environment, characterised by challenges of varying degree, is itself demonstration of either a genuine commitment to the Afghanistan mission, or a lack thereof. Therefore the above hypotheses can be extended in scope to appreciate the dimension of time, including the assumption that a strong motivation of threat balancing and strong alliance dependence together dictate better, perhaps generally more pro-active, adaptation on the ground. In this respect, "mavericks" (if there are any) may also be expected to do well, but specifically when measured against their own priorities.

Because genuine adaptation seems to occur in a number of cases, we also expect that as demonstrated advantages of this are observed on the ground, a kind of collective learning process is induced. But given the less than genuine interest in the Afghanistan mission on top political decision-making levels in a number of countries, this learning process will lead to only mixed results and imperfect

\footnotetext{
${ }^{4}$ Except, perhaps, for the value attached to successfully performing the role of "good servant."
} 
emulation of others' "best" or "relatively good" practices. The primary medium of this learning process is expected to be the "coalition owner," the US, with others largely evading responsibility for picking directions in a forward-looking process of adaptation. Thus, largely in response to US calls for change and guidelines regarding how to do it ("establish a Provincial Reconstruction Team", "deploy Operational Mentoring and Liaison Teams", "a civilian surge is required"), countries may follow a logic of appropriateness, and simply go with the pack. In other words they may be merely going through the motions in some of the cases. A degree of institutional isomorphism is hypothesised therefore, with inevitably mixed results, under US (coalition owner) leadership. US hegemony in this respect is seen as so much of a determining factor that out of all or any "strivers" within the coalition, a distinct title, that of "coalition shepherd", befits the US.

In the overall contribution-adaptation process, in both of its phases, "threat balancing" is expected to be of generally lesser significance, compared to "alliance dependence", in a context where often even the coalition shepherd has difficulties explaining the security policy rationale of the Afghanistan mission, in exact strategic terms. There are a number of profound, implicitly influential reasons why this may be the case. This is elaborated on in the next section.

\section{A conceptual detour: Interpreting threats, costs, and benefits}

Cost/benefit calculations do not work in Afghanistan's case (better than elsewhere), for a number of reasons. Examining costs and benefits in terms of threat-balancing, that is, in terms of how ISAF paticipants' policies and strategy affect different threats and, consequently, the security of the coalition's members certainly ought to be part of any such calculation. If there is a net decrease in threat levels, this may be deemed a positive result; if there is a net increase, it is a negative result. If a threat is eradicated, that clearly constitutes success. 
This may be characterised as a disaggregated approach to evaluating the Afghanistan mission as one which can be defined as aiming to tackle several, noninterlinked threats at the same time - for example those of terrorism and narcotics. This approach faces major epistemological, conceptual, and methodological challenges, however. Several of these are outlined below:

- Whether the Afghanistan mission is a "success" or a "failure" should also be assessed holistically, not only in disaggregated, reductionist analyses of whether al-Qaida operatives are (still or again) present in Afghan territory, or of how much (more or less) heroin is traded on the world market from Afghan sources.

- Counter-productivity is possible; contributions to, and by, coalitions serving a cause cannot be automatically assumed to be a net positive (e.g. in the case of mutually incompatible goals, such as winning hearts and minds of the locals and destroying poppy fields).

- Not only current threat levels and associated indicators but also threat scenarios need to be borne in mind. These may well suggest a clearer threatpolicy nexus than empirical data at present. For example, the threat of terrorism would likely grow if al-Qaeda could again gain a stable foothold and operate training camps in eastern and southern Afghanistan.

- Afghanistan cannot be treated as an isolated unit of analysis, as though it would exist in a vacuum. When answering whether there are vital interests at stake, one has to take a regional outlook and ask whether involvement is necessary in Afghanistan's entire region as such.

- ISAF's is a coalition effort that only works if the entire coalition puts overall sufficient effort into achieving common objectives. The interdependent nature of coalition members' achievements is such that, in terms of investments and pay-offs, coalitions simply do not work as shareholder companies may do. 
- Simplistic cost/benefit analyses do not work as other motives play a role. Foreign policy role conceptions, state and national identities, principles of solidarity, humanitarianism, notions of a responsibility to protect, biases about Afghanistan, its history, its people, and the wider region, casualtyaversion, organisational interests, domestic political needs, public attitudes towards the United States, and many other factors weigh in, and together determine a country's Afghanistan policy.

The most important "threats" - that is, consistently securitised issues - related to Afghanistan are those of jihadist terrorism, originating from prospective training camps and potential "state capture" there upon a partial or complete takeover of power by elements of the jihadist movement, and the heroin trade and its source, i.e. poppy cultivation in Afghanistan. That these be deemed threats requires subscribing to their securitisation which, as much as a difference in terms of this can be claimed to exist, is somewhat more of a controversial issue in the case of the drugs trade, in regard to legalisation and medicalisation which are sometimes put forward as possible solutions to it (see e.g. Senlis, 2007). ${ }^{5}$

The possible overall counter-productivity of the Afghanistan mission is an empirically relevant concern, and, as a result, an intensely politicised issue in the case of both terrorism and the drugs trade. Concerns are raised in the discourse related to terrorism whenever jihadist militants themselves name Western troops' presence in Afghanistan as one of their reasons for waging war against the West, in their propaganda messages. In the case of the drugs trade, for a long time in the wake of the 2001 intervention, poppy cultivation expanded in the country, and this

\footnotetext{
${ }^{5}$ Subscribing to an approach whereby one only takes into account threats relatively consistently securitised also entails not considering poliomyelitis as a threat, whereas this could be debated in the case of Afghanistan. One of the only few remaining hotspots of poliomyelitis, after it has been eradicated in much of the world, is the border region of Afghanistan and Pakistan. Armed conflicts there significantly hamper vaccination efforts which would require multiple rounds of oral vaccination to each children in need of being immunised. Given that this makes the eradication of the disease difficult in the current circumstances, the poliomyelitis virus could eventually pose a risk even to populations distant from the region, with likely carriers being members of the Afghan and Pakistani diasporas, travelling to locations around the globe by air and otherwise.
} 
trend also elicited criticism, given the perception that ISAF and the West in general were making this problem worse themselves somehow.

Nevertheless Afghanistan's supposed "negative externalities", in the form of the "output" of terrorism and drugs, can be measured in some concrete dimensions. Key indicators to look at in terms of "threats" to be balanced therefore can be identified. Such might be the number of citizens of a particular country who die or are wounded in terrorist attacks by jihadist militant groups targeting specifically citizens of that country; or the number of people experiencing opiaterelated health problems undergoing treatment in a particular country, or the amount of opiates intercepted at the borders of a particular country. Yet measurements in these dimensions are not sufficient for a thorough assessment of either threat levels or of a country's motives in its Afghanistan policy. Moreover, they also fail to capture how the threats concerned really work.

In order to shed more light on the transnational threat mechanisms involved, Marton (2009) uses the concept of "issue-related security complexes" to describe "webs or systems of security relationships within which interdependence is higher than in general", connected not to "sectors" as in the analysis of Buzan, Wæver \& de Wilde (1998), but to "issues" that would be hard to locate within any and just one of Buzan, Wæver and de Wilde's sectors. Take the example of jihadist terrorism: an issue/threat that matters in the political, the military, the societal, and even the economic sectors of analysis. Marton therefore proposes that:

The description of issue-specific security complexes is necessarily more than the adding up of issue-specific patterns of [negative externalities emerging from zones of armed conflict]: one also needs to describe the mechanisms that dynamically shape [negative external security effects], by explaining how qualitative, quantitative and directional shifts (...) occur, and what predictive 
models we may use in analysis, to foresee similar shifts in the future. (Marton, 2009: 97)

Both in the case of jihadist terrorism and the drugs trade, "carriers" of these threats, as well as "mechanisms" deflecting/re-directing the flows related to them, can be identified, with some overlap between the two concepts. Carriers may be human networks (in a practical sense), and structural conditions and ideas (in an abstract sense). An example of "deflecting mechanisms", in the case of the drugs trade, is how mid-stream interdiction or at-source eradication efforts in counter-narcotics operations may replace trade and smuggling routes as well as, even, the geographical sources of production, just as this occurred to the Golden Triangle, with some of the production of opiates migrating from there to Afghanistan over the long term. Law enforcement or overseas counterterrorist actions can work in similar ways by dislocating, replacing, and diverting the human networks as well as the financial flows behind terrorism. Even anti-terrorism, the defensive approach to tackling terrorism, can have such effects by raising the costs of attacking certain targets as a result of which other targets will be preferred by the terrorists (Enders \& Sandler, 2006: 20).

The possible counter-productivity of counternarcotics activities in Afghanistan has already been highlighted, and indeed this is why calls for restraint appeared, and US counternarcotics efforts were redirected from crop eradication to interdiction and to the targeting of bulk traders of opiates. In addition, in light of the deflecting mechanisms discussed above, the questionable overall productivity of counternarcotics activities needs to be highlighted as well, especially on the supply side and, in general, "up-stream". The trade may be merely deflected from a current source to a replacement source, should counternarcotics efforts lead to (thus Pyrrhic) success. 
It is in the case of terrorism that one observes some of the most interesting and perplexing effects: a weak state in Afghanistan, where Western troops are bogged down, works as a kind of militant magnet and deflects threats from Europe, North America and elsewhere in the broader Middle East, even as it paradoxically also leads to threats, in other cases, in just these locations. Thus there is deflection taking place in the direction of Afghanistan and Pakistan, as well as negative externalities suffered from there, at the same time.

The following example should be considered as useful illustration of this. There has been, in recent years, an "exodus" of German (including German-born and ethnically German) Islamists to border areas of Pakistan in Waziristan. Among them were the members of the so-called "Sauerland cell", some of whom went to Pakistan to fight in Afghanistan on the side of the Islamic Jihad Union. In the retelling of one of the members of the group, they did not perform up to expectations in attacking a US Army base in eastern Afghanistan, and in trying to mount ambushes with other guerrillas (ET, 2009). They were told by their comrades that for them in Europe it might be easier to carry out an attack. This turned out not to be the case, as German police eventually obtained timely information on their activities and raided their hideout in the autumn of 2007, before they could carry out the bombings that they were planning.

Attributing motives to terrorists is no easy analytical challenge, either. The members of the Sauerland cell may have been especially upset, based on their own account, by the kidnapping of a Muslim man and German citizen, Khaled el-Masri, in Macedonia, by the CIA (Musharbash, 2009). El-Masri was confused with a known terrorist operative going by the same name; the incident happened in 2003. Nevertheless, this was certainly not at the root of all of the animosity of the members of the Sauerland cell towards the US, Western culture, and even Germany, and the incident seems rather but a trigger that pushed them over the brink. This sort of puzzle was recently inconclusively discussed in a debate over whether "Lady Gaga or the occupation in Palestine" is more of a source of frustration and grievance for 
Islamists in general (Hegghammer, 2010). While this is not necessarily the most convenient way to frame the underlying issues, it is illustrative of the difficulties of identifying "root causes" behind terrorism. The lack of true comprehension is also evident in the debate in Britain over whether a quick exit from Afghanistan would embolden or silence radicals rather, there and elsewhere. And it also manifests in the case of the US where drone strikes in Pakistan led to a debate over whether it is worth killing known al-Qaida operatives at the cost of killing civilians in collateral damage, thereby letting Pakistani militant organisations gain a salient recruiting tool.

Theoretically speaking, the only viable, remaining assumption is a modest one. It is assumed that (i) threat balancing might be a weak, but on its own clearly insufficient, motive to be present in Afghanistan for a country experiencing public health and crime effects of the transnational drugs trade. ${ }^{6}$ At the same time it is assumed that (ii) threat balancing may be sufficient cause, even on its own, for involvement in Afghanistan for a country facing the prospect of terrorist attacks that could receive critical logistical aid from militant safe havens in Pakistan's border regions: the safe havens that may be expected to relocate to the other side of the border, should the Afghanistan mission be abandoned, and should it turn into a clear failure.

Having said that, given the uncertainty over threat mechanisms, and considerations of possible counter-productivity, these motivations may not amount to more than ambivalence and uncertainty regarding whether the threats concerned are effectively "balanced" or, to the contrary, enhanced by the Afghanistan mission. This may result in an unsure identity for countries participating in the ISAF coalition, but generally tending towards the box for "servants," in terms of the categories introduced in Figure 1.1. Framing this in a political economy language, the concern is that the Afghanistan undertaking is an "impure (that is, a partly

\footnotetext{
${ }^{6}$ Perhaps it would be better to write off the possibility of a counternarcotics motive overall, but this could seem to contradict an existing consensus that this motive does and should play a role. That consensus itself may be only present on the surface, and results from a number of factors. Examining this possibility, however, is not part of the investigation undertaken in this article.
} 
excludable and rival) public good." Furthermore, the possibility that instead of only public and private goods the mission may also produce public and private "bad," also exists, and is reckoned with. Hence the strategic ambivalence of the mission which is only mitigated by the conviction (as long as it exists) of the merits of the mission on the part of the coalition shepherd, the U.S., and other countries' "alliance dependence" towards it.

\section{Refining theory: further factors informing a coalition's prospects}

As already indicated, there is a number of factors co-determining a country's investment of effort in coalition undertakings of various sorts. Foreign Policy Analysis deals with these as a by now distinct field of research, and a number of excellent studies ${ }^{7}$ have already dealt specifically with the issues of "coalition burden-sharing" and "intra-alliance conflicts" in the past. For further insights, this literature shall now be discussed with the Afghanistan case in mind; the latter novel in some respects, while it at the same time conforms to existing expectations in others.

The existing literature tells us that countries join coalitions in order to achieve at least partly common or compatible goals. Doing this in alliances, they spread costs and risks, and they gain additional legitimacy for certain actions, while they pool resources together to collectively dispose of quantitatively and qualitatively enhanced capabilities and augmented capacities. From an alliance's collective perspective, an individual coalition member's contribution can be important in making available a missing or "niche" capability or by adding critical mass to a coalition. Any new member that joins an alliance is generally likely to increase the legitimacy of collective action, and it mitigates the burden to be shared by the coalition, by taking some of the costs and risks. An important special case is when a coalition member becomes vital, because physical access or crucial sections

\footnotetext{
${ }^{7}$ See footnote \#3 for a list of relevant references.
} 
of logistical routes to an area of operations may be granted exclusively through its territory. A good example of this sort of bottleneck-country is Egypt, with its control over the Suez Canal, vital for operations in the Gulf Region and beyond. Pakistan has a similarly exceptional role in providing the vital artery of logistical support to the Afghanistan mission.

There are potential downsides to building coalitions. Maintaining them in the face of intra-alliance quarrels may be costly itself. To set common objectives, individual member countries may need to compromise over their original goals. This is just what a preventive approach to intra-alliance conflict resolution might entail, and it translates into costs for the coordinating/compromising party.

An often considered lesson of coalition operations involving the US and other countries is that capabilities may not necessarily be enhanced in collective action. For this reason, in January 2002, Donald Rumsfeld famously stated, 'the mission must determine the coalition, and the coalition must not determine the mission. If it does, the mission will be dumbed down to the lowest common denominator, and we can't afford that.' Rumsfeld was secretary of defence at the time of saying this, and he spoke about US interests in light of the experiences of the Kosovo campaign of 1999 and the 2001 intervention in Afghanistan. In the Kosovo campaign, the US Department of Defense complained about having to wage "war by committee" in the NATO framework, while supplying the larger part of key assets and capabilities to the mission. Subsequently, in Afghanistan, the US was initially not particularly keen on accepting offers of cooperation from its NATO allies who even invoked Article 5 of the North Atlantic Treaty, at least nominally showing their readiness to provide support.

In his above quoted statement, Donald Rumsfeld disregarded advantages of increased legitimacy. Contrary to this, the 1994 US intervention in Haiti is an excellent example, from long before Kosovo, of when the US consciously multilateralised a foreign mission, with no particular military rationale, simply to gain added legitimacy in the eye of its domestic population as well as in the eye of 
Haitians (Kreps, 2007). Later on this became an important consideration behind accepting and even urging more allied contributions in Afghanistan.

Generally destabilising factors in coalitions revolve around security dilemmas and mistrust. On the basis of Snyder's (1997) and Wilkins' (2006) concepts, the former stem from the possibility of abandonment by allies and of subsequent entrapment in a losing alliance, while the latter tends to develop (i) if burden-sharing is inequitable within a coalition, (ii) if commitments are not kept in good faith or (iii) if genuine, meaningful consultation does not take place over contentious issues, such as corrective adjustments to originally equitable burdensharing arrangements.

\section{Theoretical clues for understanding ISAF burden-sharing}

The following initial observations can be made about ISAF, and coalition operations in Afghanistan, in regard to what has been presented in the overview of the literature thus far.

- The military capability gap plays less of a role in the generally low-tech counterinsurgency (COIN) campaign underway in Afghanistan. This does not mean that it does not play a role at all. But over time, the human resources that are most vital in COIN could theoretically be used with similar efficiency across the coalition, if there was even and full commitment to the mission. Nevertheless such deficiencies of the ISAF coalition as the lack of adequate and sufficient long-range and intra-theatre airlift capacities on the part of many of its members, as well as other issues, can be mentioned in this context. ${ }^{8}$

- For an ideal counterinsurgency-force to population ratio, adding a greater mass of troops would have been a requirement, but, beyond struggling to

\footnotetext{
${ }^{8}$ NATO's Strategic Airlift Interim Solution (SALIS) and Strategic Airlift Capability (SAC) have been the organisation's two main responses to this challenge so far.
} 
generate sufficient force even at their Summit meetings, only partially succeeding in this, NATO members have been and are mostly expecting the Afghan security forces, police and army, to fill in the gaps eventually, leading to a full transition to an Afghan-led effort.

- Commitments made are generally kept in good faith. The major problem is not mistrust because of a lack of respect for the principle of pacta sunt servanda, but that the commitments made may have been insufficient. Contributions were generally made not on the basis of exigencies on the ground, but in accordance with what domestic politics tolerated without too much debate.

- The legitimacy of the mission and issues of risk-sharing are closely connected. Especially in Europe, there are fears that the Afghanistan campaign may increase the risk of terrorism to European countries, by radicalising a segment of the continent's Muslim population, and this has a de-legitimising effect on the mission.

For added explanatory power, beyond what has been discussed so far, two more key works will be mentioned in this context: Fang \& Ramsay (2007) and Bennett, Lepgold \& Unger (1994).

In their game-theoretic take on the challenge of coalition burden-sharing, Fang and Ramsay show how lead nations end up having to "pay” (in a multiple sense) more within coalitions of rationally acting state parties. Their conclusions are valid within the framework of a two-state, two-stage model. NATO is not a twostate alliance, but Fang and Ramsay's study may still be relevant in regard to ISAF, for the following reasons. Fang and Ramsay use the assumption that there are potential external partners as available outside options for the lead nation; that it is not only the more traditional partners that a coalition effort's initiator can turn to. Therefore Fang and Ramsay's model appears useful in considering how a NATOled, but effectively coalition-of-the-willing type alliance, such as ISAF, currently 
depends on US lead on the one hand, and on key contributions from non-NATO countries such as Australia on the other. Fang and Ramsay find,

... an unusual relationship between ally contributions and the flexibility of alliance configurations. Specifically, allies contribute more in loose bipolar conditions than in tight bipolar conditions, but do not contribute enough in the multi-polar setting to deter search (Fang \& Ramsay, 2007: 4).

In other words, if (i) the initiator's search costs (the chances of finding alternative partners) decrease significantly, while (ii) the general environment of the coalition questions the raison d'être of a coalition, traditional allies will probably not be loyal contributors.

Yet, however convincing this may sound in the light of what can be observed in Afghanistan, directly reading Fang and Ramsay's conclusions onto the case of ISAF remains problematic for several reasons. Is Australia a "non-traditional" ally for the US, the lead nation in ISAF? Are East-Central European states, such as Lithuania, the Czech Republic, Poland, Hungary or Romania "traditional" allies because today they are NATO member states? Can we claim that "search costs" have really diminished - even though there still are not enough "boots on the ground" in Afghanistan? In the end, one cannot help but quit trying to use a twostate, two-stage model for interpreting the whole spectrum of challenges in the Afghanistan mission. One more aspect of ISAF operations does connect to Fang and Ramsay's conclusions, however. Truly vital national security threats are not entirely clearly perceived to be originating from Afghanistan at this point, by many of the key audiences concerned, and this affects governments' decisions regarding contributions, as discussed in the previous sections.

An alternative, empirically based inquiry into the dynamics of coalitionbuilding and maintenance can be found in Bennett, Lepgold and Unger's study of 
the Gulf War of 1991, previously used here for formulating the baseline assumptions of the paper. Bennett, Lepgold and Unger (1994) examined the role of five factors (three external, two domestic) in influencing the level of burden undertaken by some of the participants of the coalition that liberated Kuwait. Mildly reconfiguring their list of key factors, the external factors are:

- the balance of threat, as detailed previously;

- relative size (of a given country within a coalition): A country's contribution may show an inverse relationship with relative size within the coalition. This insight is derived from alliance theory which, partly based on neorealist considerations, predicts that smaller countries are especially likely to enter alliances merely in order to thus "contract out" the provision of their security, and that they subsequently minimise their contributions as much as possible, even in the face of demands for more equitable burden-sharing from their part by allies (Ringsmose, 2009; Kimball, 2010);

- alliance dependence: This some would refer to as "alliance importance", given that the latter is a less pejorative, more value-neutral expression - also keeping Kreps' (2010) proposition, that we think of NATO as an "iterated game" of "security cooperation", in mind. The interpretation of "alliance" here shall be sufficiently broad to include dependence on not just the NATO alliance, but on the United States as first among formally equals, both within and without the ranks of NATO: countries like Australia or New Zealand may come to mind as examples from without NATO, of countries strategically relying on good relations with the US.

The important domestic variables that Bennett, Lepgold and Unger list are: 
- the room for manoeuvre enjoyed by the executive ("executive autonomy") within a polity in formulating and implementing foreign policy free from institutional checks and balances;

- organisational interests, such as those of the military, key state agencies, the executive, political parties, and others.

This is a theoretical framework for explaining the contributions of not only an initiator and its traditional partner, as in Fang and Ramsay's two-state framework. Therefore it can be more conveniently used to evaluate contributions to a multistate coalition where roles are more diverse and the initiator's partners are more differentiated.

\section{Preliminary findings}

Some raw empirical data are presented in Table I, showing a selection of the countries involved in ISAF, and a snapshot of their troop contributions as of April 2010 to ISAF, that is, before the completion of the US surge which skewed indicators further in favour, or to the detriment, of the US.

Table I: Allied contributions in light of population size and GDP.

\begin{tabular}{|c|c|c|c|c|c|c|}
\hline & $\begin{array}{l}\text { Troop } \\
\text { contribution } \\
\text { in ISAF (as of } \\
\text { mid-April } \\
\text { 2010); ranking } \\
\text { indicated in } \\
\text { brackets }^{\alpha}\end{array}$ & $\begin{array}{l}\text { Population } \\
\text { size; ranking } \\
\text { indicated in } \\
\text { brackets }^{\beta}\end{array}$ & $\begin{array}{l}\text { GDP size } \\
(2009) \text { in } \\
\text { million USD; } \\
\text { ranking } \\
\text { indicated in } \\
\text { parentheses }{ }^{\gamma}\end{array}$ & $\begin{array}{l}\text { People per } \\
\text { one soldier } \\
\text { deployed in } \\
\text { ISAF; ranking } \\
\text { indicated in } \\
\text { parentheses }\end{array}$ & $\begin{array}{l}\text { Million GDP } \\
\text { dollars per } \\
\text { soldier } \\
\text { deployed; } \\
\text { ranking } \\
\text { indicated in } \\
\text { parentheses }\end{array}$ & $\begin{array}{l}\text { \% share in } \\
\text { ISAF's } \\
\text { overall } \\
\text { force; } \\
\text { ranking } \\
\text { indicated in } \\
\text { parentheses }\end{array}$ \\
\hline Australia & 1,$550 ;(10)$ & $\begin{array}{l}22,337,272 ; \\
(10)\end{array}$ & 997,$201 ;(8)$ & $14,411.14 ;(8)$ & $643.355 ;(15)$ & $3.45 ;(5)$ \\
\hline Canada & 2,$830 ;(6)$ & $34,096,000 ;(9)$ & $1,336,427 ;(7)$ & $12,048.05 ;(7)$ & $472.235 ;(12)$ & $4.36 ;(1)$ \\
\hline Czech Rep. & $460 ;(16)$ & $10,512,397$ & 194,$828 ;(16)$ & $22,853.03 ;(16)$ & $423.539 ;(11)$ & $1.61 ;(12)$ \\
\hline
\end{tabular}




\begin{tabular}{|c|c|c|c|c|c|c|}
\hline & & (13) & & & & \\
\hline Denmark & $750 ;(13)$ & $5,557,709 ;(16)$ & 309,$252 ;(14)$ & $7,410.27 ;(3)$ & $412.336 ;(9)$ & $3.18 ;(7)$ \\
\hline Estonia & 155; (19) & $1,340,021 ;(21)$ & 19,$123 ;(21)$ & $8,645.29 ;(4)$ & $123.374 ;(1)$ & $3.11 ;(8)$ \\
\hline Finland & $100 ;(21)$ & $5,359,500 ;(17)$ & 238,$128 ;(15)$ & 53,$595 ;(21)$ & $\begin{array}{l}\text { 2381.280; } \\
(21)\end{array}$ & $0.44 ;(20)$ \\
\hline France & 3,$750 ;(4)$ & $65,447,374 ;(4)$ & $2,675,951 ;(3)$ & $17,452.63 ;(10)$ & $713.586 ;(16)$ & $0.76 ;(18)$ \\
\hline Germany & 4,$665 ;(3)$ & $81,757,600 ;(2)$ & $3,352,742 ;(2)$ & 17,525.74; (11) & $718.701 ;(17)$ & $3.29 ;(6)$ \\
\hline Hungary & $335 ;(17)$ & $\begin{array}{l}10,013,628 ; \\
(14)\end{array}$ & 129,$407 ;(18)$ & $29,891.42 ;(18)$ & $386.289 ;(8)$ & $1.45 ;(13)$ \\
\hline Italy & 3,$300 ;(5)$ & $60,325,805 ;(6)$ & $2,118,264 ;(5)$ & $18,280.54 ;(12)$ & $641.898 ;(14)$ & $1.36 ;(14)$ \\
\hline Lithuania & $145 ;(20)$ & $3,339,227 ;(20)$ & 37,$254 ;(20)$ & 23,029.15; (17) & $256.924 ;(6)$ & $1.35 ;(15)$ \\
\hline $\begin{array}{l}\text { Netherlands } \\
\text { (before the } \\
\text { gvt's fall) }\end{array}$ & 1,$885 ;(8)$ & $\begin{array}{l}16,608,750 ; \\
(12)\end{array}$ & 794,$777 ;(9)$ & 8,$811 ;(5)$ & $421.632 ;(10)$ & $3.29 ;(6)$ \\
\hline New Zealand & $225 ;(18)$ & $4,367,700 ;(19)$ & 117,$795 ;(19)$ & 19,412; (14) & $523.533 ;(13)$ & $1.88 ;(11)$ \\
\hline Norway & $470 ;(15)$ & $4,880,000 ;(18)$ & 382,$983 ;(13)$ & $10,382.97 ;(6)$ & $814.857 ;(18)$ & $2.31 ;(10)$ \\
\hline Poland & 2,$515 ;(7)$ & $38,192,000 ;(8)$ & 430,197; (11) & $15,185.68 ;(9)$ & $171.052 ;(3)$ & $1.28 ;(16)$ \\
\hline Romania & 1,$010 ;(12)$ & $\begin{array}{l}22,215,421 ; \\
(11)\end{array}$ & 161,$521 ;(17)$ & 21,995.46; (15) & $159.921 ;(2)$ & $1.24 ;(17)$ \\
\hline Spain & 1,$270 ;(11)$ & $46,030,109 ;(7)$ & $1,464,040 ;(6)$ & $36,244.18 ;(19)$ & $\begin{array}{l}\text { 1152.787; } \\
(20)\end{array}$ & $0.71 ;(19)$ \\
\hline Sweden & $485 ;(14)$ & $9,354,462 ;(15)$ & 405,$440 ;(12)$ & 19,287.55; (13) & $835.959 ;(19)$ & $3.71 ;(14)$ \\
\hline Turkey & 1,$795 ;(9)$ & $72,561,312 ;(3)$ & 615,$329 ;(10)$ & $40,424.12 ;(20)$ & $342.802 ;(7)$ & $0.22 ;(21)$ \\
\hline $\begin{array}{l}\text { United } \\
\text { Kingdom }\end{array}$ & 9,$500 ;(2)$ & $62,041,708 ;(5)$ & $2,183,607 ;(4)$ & $6,530.7 ;(2)$ & $229.853 ;(5)$ & $4.35 ;(2)$ \\
\hline United States & 62,$415 ;(1)$ & $\begin{array}{l}309,218,000 ; \\
\text { (1) }\end{array}$ & $14,256,275 ;(1)$ & $4,954.22 ;(1)$ & $228.411 ;(4)$ & $4.16 ;(3)$ \\
\hline
\end{tabular}

${ }^{\alpha}$ Source: ISAF-P (2010a).

$\beta$ Source: http://en.wikipedia.org/wiki/List_of_countries_by_population, as accessed on 1 May 2010.

$\gamma$ Source: IMF World Economic Outlook Database, April 2010 [IMF 2010].

$\delta$ Source: IISS

To point out improportionality in burden-sharing, it may be sufficient to highlight the United States, the Netherlands and the United Kingdom, and their exceptionally great contributions, specifically in regard to the ratio of soldiers deployed to population (rows for the three countries are marked in bold). 
Another possible, raw measure is calculating rank correlations in the various dimensions in which "relative size" can be interpreted, for example by comparing GDP rankings to troop contribution rankings. Spearman's rank correlation coefficient shows strong positive rank correlation for GDP and troop contribution rankings $(\varrho=0.916)$. Especially Finland (not a member of NATO) seems to be an outlier here in a negative sense (having the $15^{\text {th }}$ largest GDP and the smallest troop contribution). Overall, the post-Cold War or post-communist NATO-member EastCentral European countries are all major contributors in nominal terms; remarkably, non-NATO members Australia and New Zealand are generally pulling according to their GDP-proportional weight even while some NATO members do not. At the same time, that there are only a few outliers, and rank correlation is so strong, may reveal something about peer expectations within the alliance, as it seems plausible to assume that what is observed may be more than mere coincidence; even bearing in mind that Table I provides but a somewhat random and arbitrary snapshot.

Unfortunately, the various measures of troop contributions do not tell us much about non-military contributions which are much more difficult to assess and might alter findings concerning the strength of the relative size hypothesis. Of the countries in Table I, the UK, Germany, and Italy had special responsibilities for many years in the domains of counternarcotics, police training, and the organisation of Afghanistan's judiciary, respectively. These countries as well as others such as Sweden, Norway, or Canada are important aid donors. As to smaller countries, despite being relative dwarves, the Czech Republic, Hungary, and Lithuania led Provincial Reconstruction Teams in different Afghan provinces (Logar, Baghlan, and Ghor, respectively), at the same time as they were providing Operational Mentoring and Liaison Teams (OMLTs), trainers, and in other ways contributing to the coalition effort. As one observer notes, there is a need to 'recognize the degree to which so many countries have mission-critical responsibilities in Afghanistan' ('Anan', 2010). 
Furthermore, the "number of people per one soldier deployed" and "GDP dollars per one soldier deployed" may be more appropriate measures of whether a country is "punching" below or above its weight. Spain, along with Finland, is identified as an under-contributor in this respect. Their "deviant" behaviour might call for an explanation. A generally more interesting finding is that contrary to the thesis that small countries exploit the great in alliances (Ringsmose, 2009; Olson, 1966), in the case of ISAF, frequently the opposite can be observed, with relative dwarves such as the Czech Republic, Lithuania, or Hungary falling below the arithmetic mean of the GDP-dollars-to-soldiers-deployed ratio while France, Germany, or Spain provide in this comparison relatively less. Nevertheless any true test of the tenets of Alliance theory (with a capital 'A') should not be restricted to the ISAF alliance (with a small 'a') in an age when parallel UN, CSDP, OSCE, NATO, and other national missions as well as general NATO and CSDP requirements impose diverse and interdependent burdens, across the globe, on most of the states concerned. Especially with the increasingly prominent idea of a "securitydevelopment nexus" in mind, it should be noted that some even contemplate including countries' share of international development cooperation as an input in aggregated burden-sharing assessments (Hartley \& Sandler, 1999: 668). To posit a likely explanation for what has been observed, the relatively small may be compensating for their generally cost-minimising approach in Alliances by doing more in Alliances' individual missions, be this under pressure or by their own choice.

\section{Towards an integrated model of ISAF burden-sharing}

To develop an integrated model of the heretofore discussed variables, with relative size disregarded for now, and alliance dependence, threat balancing, domestic constraints and organisational interests remaining to be incorporated, in earlier 
work $^{9}$ we relied to a large extent on Auerswald's integrated model (Auerswald, 2004: 643$)^{10}$ for further simplification in the interest of successful operationalisation. The last two of Bennett, Lepgold and Unger's five variables, i.e. domestic constraints and organisational interests, are thus presented as "executive strength" and "public support."

The decision-making moment of the model we conceptualised as one in which states already in the mission area as part of the coalition decide how to move on from an initial commitment posture $(\mathrm{CP})^{11}$ to one of three options $\left(\mathrm{O}_{1-3}\right)$ available to them, given the mediating variables' influence. This largely conforms to the 2006-2011 period in Afghanistan, the period starting from ISAF's completion of expanding its area of operations across Afghanistan, up to the envisioned end-point of the US-led "surge".

CPs were either strong, medium, or weak to begin with (CP-Major; CPMedium; CP-Minor). The options available are a small set. Being the first country to withdraw from Afghanistan without a particularly salient prior contribution was not apparently part of the considered set of options, as it may have been seen as cost-prohibitive specifically in terms of (ally) reputation costs. $\mathrm{O}_{1}$ was to maintain one's current level of commitment even if this was criticised by peers and especially by the coalition initiator. $\mathrm{O}_{2}$ was to incrementally increase commitments as the

\footnotetext{
${ }^{9}$ In the opening chapter of the forthcoming book: Marton, Péter - Hynek, Nik, eds. (2011) 'Statebuilding in Afghanistan: Multinational contributions to reconstruction'. London: Routledge.

${ }^{10}$ Auerswald builds an integrated model of some of Bennett, Lepgold and Unger's component variables, one that is well-suited to analysing potentially even the case of Afghanistan, albeit it was devised to recover determinants of NATO countries' policy towards Operation Allied Force in Kosovo. In Auerswald's model „alliance dependence” does not receive as great emphasis as in this article, given the context in which it was developed. The latter variable, important in Bennett, Lepgold and Unger (1994), is dealt with essentially as but one component of Auerswald's factors affecting a country's propensity to partake in the provision of a collective good. This is one of the reasons why we propose an altered integrated model here.

${ }^{11}$ This may be measured in quantitative terms, e.g. of the number of troops deployed, as well as by qualitative measures such as the absence or presence of caveats restricting what types of engagement a country's troops may become involved in, or the difficulty of the geographical and social terrain which significantly vary across different areas of operations.
} 
situation on the ground deteriorated and demands for this were made by peers. $\mathrm{O}_{3}$ was to make a highly visible commitment with a firmly fixed, albeit possibly renegotiable deadline, and then exit, thus avoiding major criticism in the wake of an acknowledged, significant contribution (this we term a "noble exit"). Since such policy still leaves the coalition to its fate in the mission area, this option may have been more available to countries with $\mathrm{CP}$-High to begin with.

Figure 1.3: An integrated model of decision-making related to contributions to ISAF, configured to the context in Afghanistan circa 2006-2011.

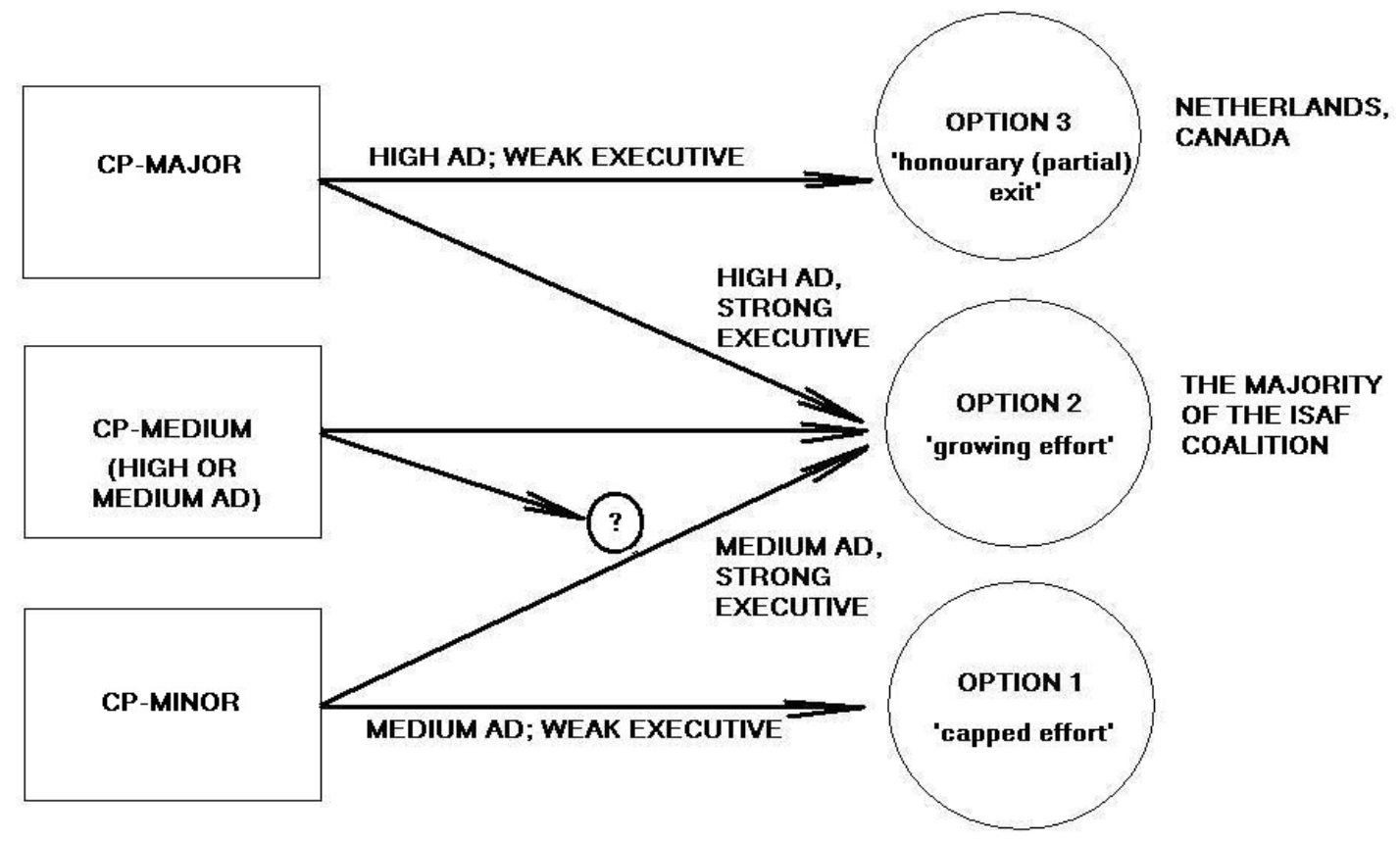

Given how vaguely understood it tends to be for the reasons presented in the second section, threat balancing (TB) is seen as a factor which either had or had not influence. Alliance dependence (AD) is assumed to be either high or medium, based on the premise that countries which are not dependent on the alliance of the states making up ISAF, in one meaningful way or another, would not be there in Afghanistan at all. Public support for operations in Afghanistan is generally low across the coalition's members, Poland and Turkey possibly being some of the "worst cases" from the point of view of a decision-maker intent in these countries 
on contributing to the common effort in Afghanistan (based on data in Kreps, 2010: 195).

The integrated model, presented in Figure 1.3 then assumes that if TB plays a role and/or if $\mathrm{AD}$ is strong, only $\mathrm{O}_{2}$ and $\mathrm{O}_{3}$ are available as options, with executive strength making the difference. If the executive is challenged on Afghanistan policy and in danger either of fragmenting or of being outflanked by a combination of the opposition, $\mathrm{O}_{3}$ may provide an honorary exit, saving face among peers.

At the time of devising the model, only the Netherlands and Canada seemed to qualify as plausible examples, with the reservations that in the Netherlands' case the governing coalition behind the fourth cabinet of Jan Peter Balkenende collapsed in February 2010 not only related to the Afghanistan mission, having been a fractious grand coalition from its inception, and that for the Canadian leadership of PM Stephen Harper the Netherlands' announced withdrawal of troops possibly facilitated avoiding a renegotiation within NATO of the finality of the 2011 enddate for Canadian troops' deployment in Kandahar province. ${ }^{12} \mathrm{O}_{1}$ and $\mathrm{O}_{2}$ were assumed to be the only available options for the rest of the coalition, with the definitive capping of commitments, as $\mathrm{O}_{1}$ implies, rather unlikely in the current circumstances, and hypothesised here as an option for the weak executive of a country whose alliance dependence is medium only. As an overall determining variable, US hegemony matters, however, and if mid-2011 turns out to be a strategic watershed moment, with troop reductions beginning in the Afghan theatre, the US will eventually lead the gradual wrap-up of coalition operations itself.

\footnotetext{
${ }^{12}$ It also needs to be borne in mind that the Netherlands and Canada are not planning to completely move past a military role, given their involvement in the training of Afghan National Security Forces. At the same time, other aspects of their involvement will also continue past mid-2011; for example, in the wake of its mission in Uruzgan province, the Netherlands returned to the north of Afghanistan, to Kunduz province, with a police training mission. This is why the $\mathrm{O} 3$ option in the scheme is eventually indicated as an honorary, but potentially only partial exit.
} 
The integrated model may, by Spring 2011, be determined to have partially inaccurately predicted the dynamics preceding mid-2011: it is found that in the period spanning mid-2010 and Spring 2011, out of the twenty countries included in Table I, only nine increased their troop contributions significantly, that is, with over one-hundred troops. Nine increased their troop contributions only by a token or not at all, and two countries even decreased their contributions [Norway and Denmark] (ISAF-P 2011). Canada, whose role in Kandahar was already set to expire, actually increased its contribution by Spring 2011. Depending on whether one accepts small increases as a "growing effort", one may arrive at different assessments of the coalition's performance in force generation. The tokenism observed, and that an outgoing contributor such as Canada still needed to fill in gaps, may suggest either profound deficiencies in this respect, or that the expectation that even the coalition leader was making preparations for eventually downsizing its effort, affected coalition partners' behaviour. Moreover, as indicated before, these quantitative changes do not reflect what may have changed in qualitative terms; for example any new forms of contributions that may have appeared in individual countries' portfolios.

In light of recent research by Ali Ashraf (2011), a rethinking of the integrated model in Figure 1.3 may be warranted to reflect the operation of key variables since the beginnings of ISAF (not only for 2006-2011). This requires, instead of the in medias res approach of our model above, explaining why CPs High, Medium, or Low emerged as outcomes in the first place (the starting points of our first integrated model). In Ashraf's own model (2011: 75), alliance dependence and balance of threat play a key role at $t_{0}$, just as in our Figure 1.1, but in addition to these, the collective-action dilemma is referenced as well. The effect of this mix of three components is then mediated by executive strength to implement a rational contribution to the coalition's operations, and is further differentiated by public opinion and the absence or availability of military capability to deliver a contribution seen as necessary further intervening variables. Ashraf's model 
challenges our assumptions on the count of relative size informing a country's approach to coalition operations. However, if it were to function this way, ISAF's empirical experience would be a paradox of small countries doing nominally more, in terms of GDP dollars to soldiers deployed, than several of the countries with greater potential in this respect, as noted before.

We therefore argue that a reconfiguration of Ashraf's model is necessary with reference to Ashraf's otherwise correctly inserted intervening variable of "military capability." The consideration of the latter, a country's set of existing capabilities, should be moved to the front, that is, to the left of the scheme, since it is well-known within the Alliance and is therefore the origo of intra-alliance calculations rather than a derivatively considered circumstance. For just this reason, writing of NATO's burden-sharing problems, Thies (1989: 364) makes the point that countries with larger defence programs and defence bureaucracies are best suited to collect and make sense of such information, thus making the most out of calling on their smaller alliance partners to contribute more as allies. This endeavour may be hindered somewhat by small countries' continuous endeavour to decrease their defence budgets. However, exactly because of thus potentially undermining the security relationship with, and the existing security guarantees from, great-power partners, small countries may be eventually more effectively pressured, and at the same time more inclined, to offer up what they have on those occasions when this is marginally more important, in the Alliance's missions. Moreover, beyond the jointly set capability development goals and coordinated capability development efforts within $\mathrm{NATO}^{13}$ themselves significant in illustrating why the capability filter should be included ahead of the loop in an integrated scheme of the contribution process (contrary to Ashraf's scheme), military capabilities are

\footnotetext{
${ }^{13}$ Institutionally, capability development within NATO is coordinated by Allied Command Transformation's Capability Development Directorate in cooperation with the Joint Analysis and Lessons Learned Center (JALLC). The Directorate is organised into five divisions. Its responsibility covers the Capability Development Process from the identification of capability development needs to overseeing implementation within the Alliance (NATO 2012).
} 
sometimes developed specifically in the context of ongoing missions, with the purpose of optimising contributions from partners, in cooperation with coalition leaders such as the United States. One of many possible examples of this is Hungary whose special operations capability was created with much U.S. assistance in the wake of 11 September 2001 - a capability now used in Afghanistan (Wagner 2011); more recently the U.S. provided financial and material support to Hungary for the development of its Joint Terminal Attack Controller capability, exactly in order to further augment its military contribution to the Afghanistan mission (Index 2012).

Figure 1.4: An integrated model of ISAF burden-sharing in the long run (based on Ashraf 2011).

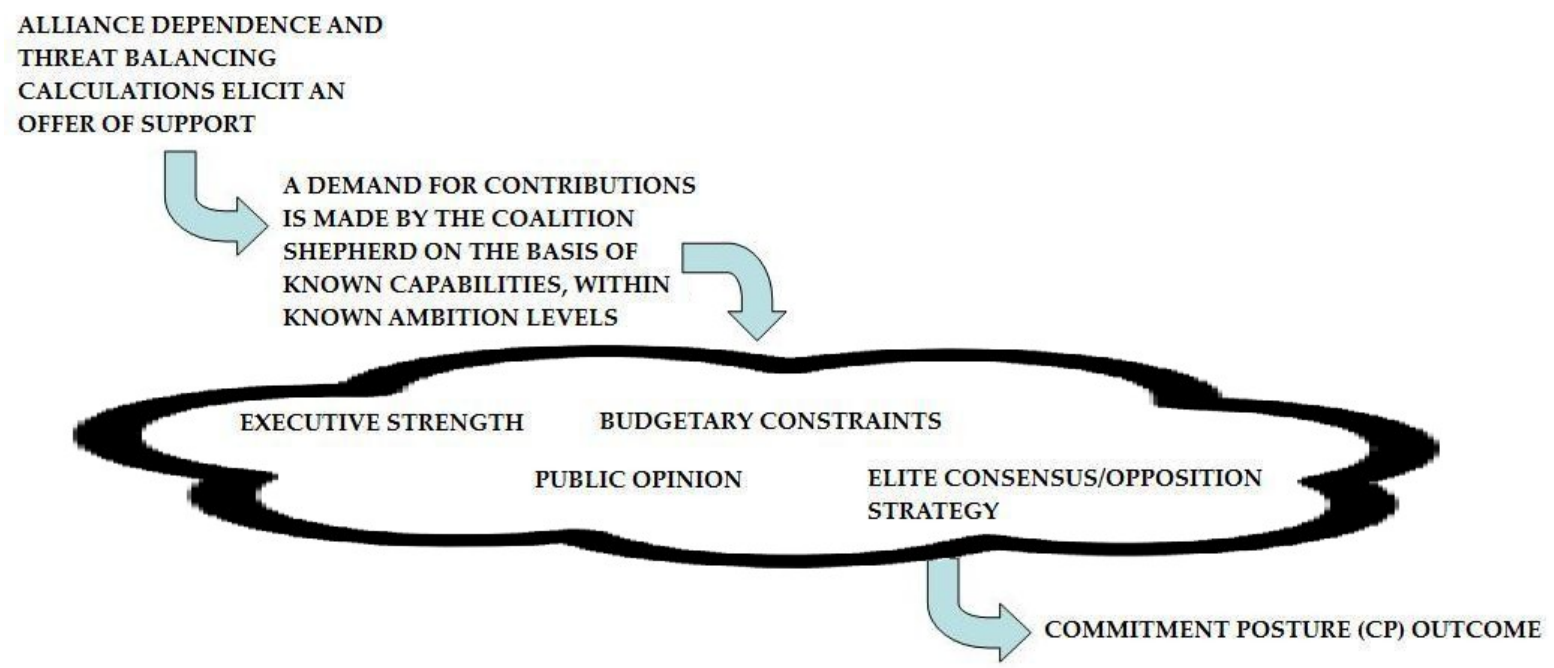

In addition, countries limit and openly state 'ambition levels' within the NATO Alliance, to thus reflect the degree to which they are ready to use existing capabilities in foreign missions.

Therefore in our integrated model we suggest the following sequence of events under the effect of the variables specified in Figure 1.4. A demand for contributions is made by a coalition's shepherd with such parameters as available 
capabilities and ambition levels in mind to countries that had in some form expressed a readiness to consider such a demand with reference to allied solidarity and shared threat perceptions (as we concluded in the second section, in most cases it will be alliance dependence informing their expression of support in ISAF). Whether a demand by the coalition shepherd is satisfied is then further mediated by interrelated, reciprocally effective variables, such as executive strength/autonomy, budgetary constraints, public opinion, and the existence or absence of elite consensus which (its absence) may translate into a strong challenge by the opposition against making a certain contribution.

(Collective-action dilemmas based on) "relative size," not taken into account above, may rather be expected to matter in terms of how genuinely and proactively a country is adapting under the circumstances it finds in Afghanistan, and as to how genuinely it is striving to achieve common goals. A relatively small country that does not have a defining impact on coalition strategy and cannot see its contribution as making a defining impact on the outcome of the coalition's efforts may not strive so much in this respect, even if it contributes to the mission significantly, above what would be its proportional share of the burden. This is the aspect of a country's contribution that a purely rationalist/materialist model interested mostly in the quantitative dimension of a country's contribution to coalition operations, will tend not to capture. Altogether, we therefore propose the alternative integrated model of ISAF operations presented in Figure 1.4.

\section{Insights regarding Afghanistan strategy}

The discussion of variables determining and mediating the level of coalition contributions in terms of forces and assets generated for the mission, and in terms of meaningful strategic adaptation demonstrated on the ground, holds relevance for Afghanistan strategy. In and of itself it is reminder that the assessment of 
individual country contributions, as in a vacuum, is a superficial intellectual exercise that does not result in a meaningful overall assessment of the Afghanistan mission. Neither is it possible to isolate the impact individual PRTs are making in their respective environments in the wider context of their operations that is dynamically changing.

A typology of different approaches to coalition policy, and to the mission in Afghanistan, by individual participant countries, allows one to conceptualise a possibly fundamental flaw in the way the mission was handled in the period between 2006 and 2009. This is the period preceding the US-led "surge," when ISAF had already extended its area of operations to the entire country, and when the mounting challenge of the ongoing insurgencies had already been realised. In regard to this period, and on the basis of the matrix in Figure 1.1, it is presented as a final baseline assumption that largely "servants" deployed to areas to the west, northwest, and north, perceived as the generally safer areas, while mostly "strivers", and the "coalition owner", that is, the US, deployed to the south, southeast, and east, perceived as hotbeds of the various insurgencies. For the sake of parsimony, the concept of "mavericks", the Kabul area, or ISAF's five Regional Commands are not used to complicate the scheme presented in Figure 1.5.

Figure 1.5: The distribution of servants and strivers in Afghanistan.

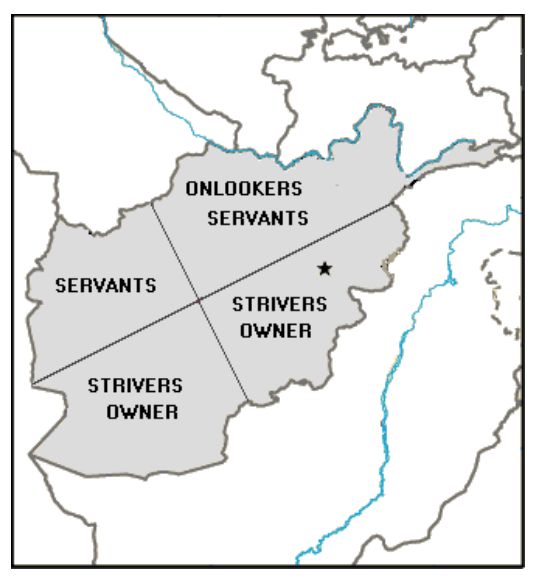


The strategic implications are manifold. Inasmuch as the above assumptions are correct, in the north the less well-resourced and, over time, less pro-actively reconfigured coalition contributions may have created ample ground for forays by insurgents, and eventually for the establishment of their stable foothold in these areas, relying on, as well as having organised, local constituencies. As a caveat it needs to be added that beyond how much individual PRTs may have strived for success, the importance of raw military strength and spending power, and differences in this respect, also need to be considered. As of end-2010, 42 out of the 46 ISAF combat battalions were still concentrated in southern and eastern Afghanistan, leaving the north less well reinforced (Peter, 2010).

Figure 1.6 shows the change of the security situation across Afghanistan based on data from the United Nations Department of Safety and Security, between 2006 and 2010. The ominous spread of the dark patches indicates how much circumstances deteriorated over these years. The contrast is strong, but at the same time it is important to note that "very high risk" areas appeared almost immediately in the wake of ISAF's expansion to the south and the east, over the course of 2006. Meanwhile, the key change is that "medium" and "high risk" areas gradually emerged in patches in the north and west as well, possibly in part as a result of the way areas of operation were allocated to different countries, and the degree to which different geographical regions were reinforced with combat units.

Figure 1.6: The changing security situation 2005-2010. (Source: the authors' work, on the basis of United Nations Department of Safety and Security maps)

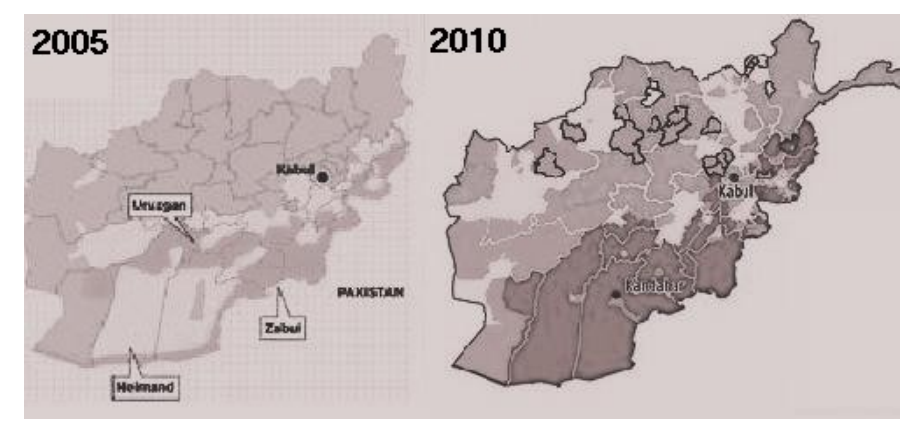




\section{Findings concerning individual countries}

Recent research and case studies, to be published in an upcoming volume, permit us to re-evaluate some of the assumptions outlined in the previous sections, and to test the country-specific hypotheses presented in Figure 1.2.

As already demonstrated, non-NATO members Australia and New Zealand are making a comparatively proportional contribution to ISAF operations, contrary to the proposition that they may be involved only as "onlookers" since they are non-NATO members. So much may be said, even if, as William Maley concludes, 'success in Uruzgan [where Austrialian troops are operating] offers no guarantee of success in Afghanistan as a whole' (Maley, 2011: 135), and, as Hoadley points out, 'New Zealand officers with field experience, are inclined to [believe that] good outcomes ... reflect creative adaptations to the varied and ever-changing security and development environments that characterize Afghanistan' (Hoadley, 2011: 150).

East-Central European NATO-members' efforts, including in leading PRTs in different provinces of Afghanistan, also need to be more carefully assessed. Their experience may be more varied than the "servant" characterisation may suggest. In their study, Marton and Wagner conclude that 'Hungary, proud of its nominally major contribution to ISAF 's efforts in Afghanistan, was never really eager to do more than just go through the motions' (Marton \& Wagner, 2011: 208). Račius contends that 'Lithuania never even considered seriously engaging in the provincial reconstruction works' (Račius, 2011: 264). Generally confirming expectations, Kulesa and Górka-Winter describe Poland as beyond 'a long history of adapting to the changing demands of the United States and other allies within NATO and ISAF in a consciously responsive manner' (Kulesa \& Górka-Winter, 2011: 223). Meanwhile, as to the Czech Republic, Hynek and Eichler posit that 'an explanation of the Czech government's motivation in this matter is that there was a successful internalization of US and NATO strategic narratives concerning the 
Allied necessity to reconstruct Afghanistan (...) seen as natural, right and legitimate' (Hynek \& Eichler, 2011: 238).

Foust discusses France, the potential "maverick" in light of Figure 1.1. He refers to the French approach as different from the U.S. approach in being more "pragmatist," since "the French do not believe they can create large-scale social change." In terms of results, however, he debates the relevance of this, and notes that while "the methods differed, but the results (...) were much the same." Moreover, France did what it did with a view "to remain a major actor within the alliance, but to do so in responsible, strategic manner" (Foust, 2011: 99-100). Therefore he concludes that France "can be placed right along the boundary of the 'mavericks' and 'strivers' boxes (...) The French military can properly be called 'strivers' in the sense that it exudes a strong sense of coalition (...) the French government can be called 'mavericks' in the sense that it independently sees value in participating in the war in Afghanistan" (Foust, 2011: 98). The one real maverick overall, contrary to prior expectations, seems to be Turkey. Vamvakas outlines why the Turkish contribution may be amongst those least fitting the alliance dependence/threat balancing framework; given how the ruling AKP government is just as interested in state and nation-building in Turkey through the policy it implements vis-à-vis Afghanistan as it is in building special ties with Afghanistan, Central Asia and beyond, through its participation in ISAF.

Several genuine "strivers" are also identified in the volume. Anthony King generally confirms the hypothesis concerning the United Kingdom, while the Netherlands, and possibly even Germany, the latter sometimes misleadingly defined as the "weakest link" in northern Afghanistan, may qualify in this category, as Rietjens and Behr show in their respective chapters. Behr emphasises that Germany eventually 'did adjust its ISAF contribution ... in the face of overtly hostile public opinion, a lack of experience, severe institutional limitations and a long-standing aversion to the use of military force (...) beginning to resemble more of a "striver" than a "servant"' (Behr, 2011: 58-59). Given that the German 
contingent is the most significant in the area of operations under ISAF Regional Command-North, this clearly was significant change. It has come belatedly, by a time by which insurgents may have established themselves a strong foothold in the northern provinces. Nevertheless Germany's reconsideration of its earlier caveats and rules of engagement allowed the coalition to adapt to the changed circumstances in the north with a less profound reorganisation than otherwise would have been needed.

The crucial assumption regarding the early weaknesses of ISAF's allocation of responsibilities, incorporated in Figure 1.5, based on the categorisation from Figure 1.1, is thus also seen as largely justified. Behr emphasises that the German position in the first few years of the ISAF engagement might be classified as that of a "servant"' (Behr, 2011: 58). Salonius-Pasternak, for his part, claims that 'Finland only very recently acknowledged the changing security challenges in Afghanistan' (Salonius-Pasternak, 2011: 187), and the experience of others, for example Hungary and Norway, seem similar in light of what Marton and Wagner and Harpviken add in their respective chapters.

As was expected, the materialist ontology behind the matrix in Figure 1.1 does not capture additional possible motives informing countries' policies, such as Norway's conflicted commitment to live up to expectations as a "peace nation" even in the Afghanistan environment. As Kristian Harpviken notes, 'The ambiguity of the $[\mathrm{PRT}]$ concept ... not only [allows] divergent narratives between nations, it also allows multiple narratives to coexist within the same nation' (Harpviken, 2011: 170).

To conclude, Figure 1.7 summarises the findings as they fit the matrix presented in Figure 1.1, and these can be compared to the hypothesised country profiles presented in Figure 1.2. 
Figure 1.7: Hypothesised country profiles

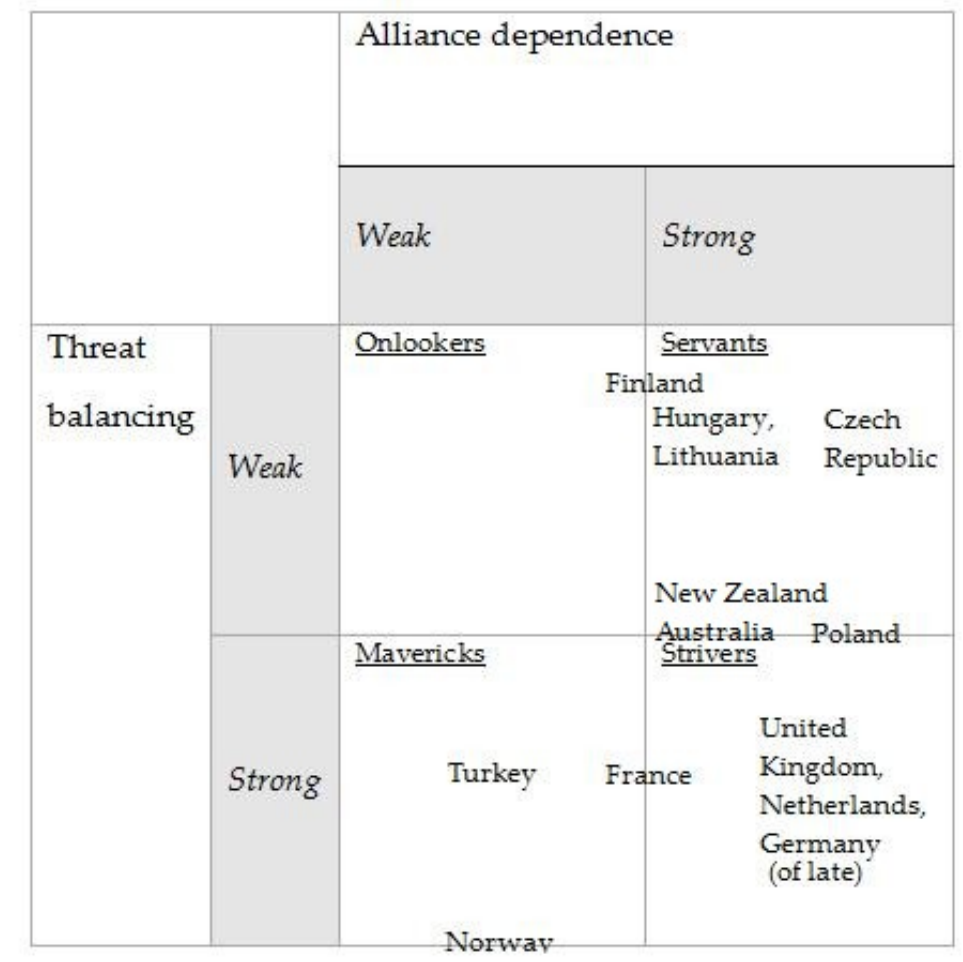

\section{Conclusions}

In spite of the many problems discussed in this paper, one does observe a certain level of strategic coherence in the coalition's approach to burden-sharing. Much behind-the-scenes work as well as overt diplomacy is taking place within the coalition to this end, led by the coalition's shepherd, the US. This increased interaction in general, together perhaps with a role played by transnational policy networks and epistemic communities, is important in maintaining the cohesion of the coalition, and the striving for more coherence in its efforts. Through the shepherd's and its key partners', that is, strivers', diplomatic efforts, as well as through key networks, intense messaging is taking place, directed at coalition partners' elites and publics, and this may result in the high correlation observed between GDP and troop contribution rankings, regarding which we presented data earlier on. 
Alliance dependence is the factor seen as playing the most significant role in the generally constructive atmosphere that one can observe on the surface even behind the scenes, in how relative size and variables connected to the domestic polity and domestic politics, i.e. executive autonomy/strength and organisational interests, play their mediating role. The effect of domestic politics is moderated, while relative size, contrary to the general assumption of alliance theory, is demonstrated to be playing the inverse of its conventionally expected role: in fact, it is just this conventional, or commonly observed, effect of calculations related to it that the extensive involvement of minor participants in the ISAF coalition may serve to compensate.

In the decision-making moment conceptualised by the paper's first of two integrated models, that is, in the period between 2006 and mid-2011, especially between end-2009 and mid-2011, it is hypothesised and partly found to conform to empirical data that, regardless of whether a country's contribution was relatively major, medium, or minor at the start of the period, a slowly growing effort could be expected from its part; however, inadequacies have also been identified in this respect. Size of contribution is, meanwhile, not enough in and of itself to gauge a country's importance, and the general role conception of ISAF participants, and how much they strive, or, conversely, merely try to serve or stand by, also plays an important role in determining outcomes; beyond the enormously important variable of the dynamically changing local circumstances in Afghanistan, and the challenges they pose.

It is therefore argued that while placing servants and onlookers with nominally/proportionally appropriate contributions in the relatively safer areas of operations may have seemed a safe or prudent approach as of mid-2006, in an interdependent strategic environment this itself may have provided incentives to adversaries to take the fight to beyond their earlier areas of activity within Afghanistan. 


\section{References}

'Anan' (2010) Reader comment to: “Discussing European Efforts at Afghan Reconstruction" by Joshua Foust. (http://www.registan.net/index.php/2010/11/11/discussing-european-effortsat-afghan-reconstruction/\#comments) (Accessed 19 November 2010).

Ashraf, Ali (2011) The politics of coalition burden-sharing: The case of the war in Afghanistan, doctoral thesis, Pittsburgh: University of Pittsburgh.

Auerswald, David P. (2004) Explaining Wars of Choice: An Integrated Decision Model of NATO Policy in Kosovo. International Studies Quarterly 48(3): 631662.

Behr, Timo (2011) Germany and Regional Command-North: ISAF 's weakest link?, in Hynek and Marton, 42-64.

Bennett, Andrew; Lepgold, Joseph \& Unger, Danny (1994) Burden-Sharing in the Persian Gulf War. International Organisation 48(1): 39-75.

Bensahel, Nora (2006) A Coalition of Coalitions: International Cooperation Against Terrorism. Studies in Conflict \& Terrorism, 29, 35-49.

Buzan, Barry; Wæver, Ole \& de Wilde, Jaap (1998) Security: A New Framework For Analysis. Boulder: Colorado/ London: Lynne Rienner.

DiNardo, R. L. \& Hughes, Daniel J. (2001) Germany and Coalition Warfare in the World Wars: A Comparative Study. War in History 8(2), April 2001: 166-190.

ET (2009) German terror suspects targeted 'US soldiers in Europe' - Summary. $\begin{array}{llll}\text { Earth } & \text { Times, } & 10 & \text { August }\end{array}$ (http://www.earthtimes.org/articles/news/280866,german-terror-suspectstargeted-us-soldiers-in-europe--summary.html) (Accessed on 12 October 2010).

Enders, Walter \& Sandler, Todd (2006) The Political Economy of Terrorism. Cambridge: Cambridge University Press. 
Fang, Songying \& Ramsay, Kristopher W. (2007) Burden-sharing in Nonbinding Alliances. Article awaiting publication. (http://www.polisci.umn.edu/ sfang/ alliances\%20JCR\%202.0.pdf) (Accessed on 23 June 2008).

Foust, Joshua (2011) France in Kapisa: A combined approach to statebuilding, in Hynek and Marton, 88-103.

Harpviken, Kristian (2011) A peace nation in the war on terror: the Norwegian engagement in Afghanistan, in Hynek and Marton, 157-173.

Hartley, Keith \& Sandler, Todd (1999) NATO Burden-Sharing: Past and Future. Journal of Peace Research 36(6): 665-680.

Hegghammer, Thomas (2010) Lady Gaga vs. the Occupation. Foreign Policy 31 March

(http://www.foreignpolicy.com/articles/2010/03/31/lady_gaga_vs_the_occup ation) (Accessed on 8 September 2010).

Hoadley, Stephen (2011) The New Zealand PRT experience in Bamyan Province: assessing political legitimacy and operational achievements, in Hynek and Marton, 139-156.

Hynek, Nik \& Eichler, Jan (2011) Post-decisional and alliance-dependent: the Czech engagement in Logar, in Hynek and Marton, 226-242.

Hynek, Nik \& Marton, Péter (eds) (2011) Statebuilding in Afghanistan: Multinational contributions to reconstruction. London: Routledge.

IMF (2010) Report for Selected Countries and Subjects. In: World Economic Outlook Database, April 2010.

Index (2012) Az USA 3 milliárd forinttal támogatja a Magyar Honvédséget. Index,

(http://index.hu/kulfold/2012/01/24/az_usa_3_milliard_forinttal_tamogatja_a _magyar_honvedseget/) (Accessed on 2 February 2012).

ISAF-P ISAF Placemat, NATO. 16 April (http://www.isaf.nato.int/images/stories/File/Placemats/Apr-16-2010placemat.pdf) (Accessed on May 8, 2010). 
ISAF-P ISAF Placemat, NATO. 6 August (http://www.isaf.nato.int/images/stories/File/Placemats/100804\%20Rev \%20Placemat.pdf) (Accessed 7 September 2010).

ISAF-P ISAF Placemat, NATO. 4 March (http://www.isaf.nato.int/images/stories/File/Placemats/PLACEMAT.MARC H\%2004..pdf) (Accessed 10 April 2010).

Jentleson, Bruce (1992) The Pretty Prudent Public: Post Post-Vietnam American Opinion on the Use of Military Force. International Studies Quarterly 36(1): 4974.

Khanna, Jyoti, \& Sandler, Todd (1996) NATO burden-sharing: 1960-1992. Defence and Peace Economics 8(1): 101-120.

Kimball, Anessa L. (2010) Political survival, policy distribution, and alliance formation. Journal of Peace Research 47(4): 407.

King, Anthony (2011) Operation Herrick: the British campaign in Helmand, in Hynek and Marton, 27-41.

Kreps, Sarah (2007) The 1994 Haiti Intervention: A Unilateral Operation in Multilateral Clothes. Journal of Strategic Studies 30(3): 449-474.

Kreps, Sarah (2010) Elite Consensus as a Determinant of Alliance Cohesion: Why Public Opinion Hardly Matters for NATO-led Operations in Afghanistan. Foreign Policy Analysis 6(3): 191-215.

Kulesa, Łukasz, and Górka-Winter, Beata (2011) From followers to leaders as 'coalition servants': the Polish engagement in Afghanistan, in Hynek and Marton, 212-225.

Maley, William (2011) PRT activity in Afghanistan: the Australian experience, in Hynek and Marton, 124-138.

Marton, Péter (2009) Grand Theory meets the Afghan case: State failure and statebuilding in an age of opaque policy-making, doctoral thesis, Budapest: Corvinus University of Budapest, August 2009. 
Marton, Péter \& Wagner, Péter (2011) 'Hungary's involvement in Afghanistan: proudly going through the motions?', in Hynek and Marton, 192-211.

Musharbash, Yassin (2009) Jihadists Describe Hatred of US as Reason for Terror Plot. Der $\quad$ Spiegel, $12 \quad$ August (http://www.spiegel.de/international/germany/0,1518,642047,00.html) (Accessed on 12 October 2010).

NATO (2012) Capability Development (CAP DEV), NATO Allied Command Transformation. Date not indicated. (http://www.act.nato.int/index.php/organization/hqsact/structure/capability-development) (Accessed on 22 February 2012).

Olson, Marcus \& Zeckhauser, Richard (1966) An Economic Theory of Alliances. Review of Economics and Statistics 48(3): 266-79.

Peter, Tom A. (2010) In deadly Kandahar, skepticism over gains cited in Afghan war review. Christian Science Monitor, 16 December, (http://www.csmonitor.com/World/Asia-South-Central/2010/1216/In-deadlyKandahar-skepticism-over-gains-cited-in-Afghan-war-review/(page)/2) (Accessed on 18 December 2010).

Račius, Egdūnas (2011) Trials and tribulations of the Lithuanian participation in the NATO ISAF mission, in Hynek and Marton, 261-277.

Rietjens, Sebastiaan (2011) Between expectations and reality: the Dutch engagement in Uruzgan, in Hynek and Marton, 65-87.

Ringsmose, Jens (2009) Paying for Protection: Denmark's Military Expenditure during the Cold War. Cooperation and Conflict 44(1): 73-97.

Salonius-Pasternak, Charly (2011) Finland's ISAF experience: rewarding, challenging and on the edges of the politically feasible, in Hynek and Marton, 174-191.

Senlis Council (2007) Poppy for Medicine Licensing poppy for the production of essential medicines: an integrated counter-narcotics, development, and counter-insurgency model for Afghanistan. June 2007 
(http://www.poppyformedicine.net/documents/Poppy_for_medicine_in_Afg hanistan) (Accessed on 12 October 2010).

Snyder, J. (1997) Alliance Politics. Ithaca, New York: Cornell University Press.

Shimizu, H. \& Sandler, T. (2003) NATO Peacekeeping and Burden Sharing: 19942000. Public Finance Review 31(2): 123-143.

Thies, Wallace J. (1989) Crises and the Study of Alliance Politics. Armed Forces \& Society, Spring 1989, 15(3): 349-370.

Vamvakas, Petros (2011) Turkey's ISAF mission: a maverick with strategic depth, in Hynek and Marton, 243-260.

Wagner, Péter (2011) 9/11 és a Magyar Honvédség. Nemzet és Biztonság, 2011/8: 6471.

Wilkins, Thomas Stow (2006) Analysing Coalition Warfare from an Intra-Alliance Politics Perspective: The Normandy Campaign 1944. Journal of Strategic Studies 29(6), December: 1121-1150. 